\title{
KOMUNIKASI YANG RELEVAN DAN EFEKTIF ANTARA DOKTER DAN PASIEN
}

\author{
Endang Fourianalistyawati, M.Psi, Psi \\ Fakultas Psikologi Universitas YARSI \\ endang.fouriana@yarsi.ac.id
}

\begin{abstract}
Communication between doctors and patients on one occasion is not always able to complete all of the efforts in the provision of information, advice, motivation of the patient, or patient compliance in order to resolve health problems. One of the aspects that contribute major impact on patient noncompliance is ineffective communication from the physician to the patient. In this paper the author discusses about how effective communication need to be raised by the physician to the patient. Effective communication is expected to overcome the obstacles caused by both sides, both doctors and patients, so that patients understand and follow the advice given by the doctor, and improve patient compliance in the treatment and resolve health problems.

Keywords: Effective Communication, Effective physician-patient communication
\end{abstract}

\begin{abstract}
Abstrak. Komunikasi antara dokter dan pasien dalam satu kesempatan tidak selalu dapat menyelesaikan semua upaya dalam pemberian informasi, nasehat, motivasi pasien, atau bahkan kepatuhan pasien dalam rangka menyelesaikan masalah kesehatannya. Salah satu aspek yang berperan besar terhadap ketidakpatuhan pasien adalah komunikasi yang tidak efektif dari dokter kepada pasien. Dalam makalah ini penulis membahas mengenai bagaimana bentuk komunikasi efektif yang perlu dimunculkan oleh dokter kepada pasiennya. Komunikasi efektif diharapkan dapat mengatasi kendala yang ditimbulkan dari kedua belah pihak, baik dokter maupun pasien, sehingga pasien memahami dan mengikuti saran yang disampaikan oleh dokter tersebut, serta meningkatkan kepatuhan pasien dalam menjalani pengobatan dan menyelesaikan masalah kesehatannya.

Kata kunci : Komunikasi efektif, Komunikasi efektif dokter-pasien
\end{abstract}

\section{PENDAHULUAN}

Komunikasi yang efektif antara dokter dan pasien merupakan salah satu kompetensi yang sangat penting dan harus dikuasai oleh dokter. Kompetensi komunikasi menentukan keberhasilan dalam membantu penyelesaian masalah kesehatan pasien. Komunikasi yang efektif dapat mengurangi keraguan pasien, serta menambah kepatuhan dari pasien. Dokter dan pasien sama-sama memperoleh manfaat dari saling berbagi dalam hubungan yang erat. Setiap pihak merasa dimengerti. Pasien merasa aman dan terlindungi jika dokter yang menanganinya melakukan yang terbaik untuk pasiennya. Ketika saling terhubung, sang dokter dapat mengerti dan bereaksi lebih baik pada perubahan perilaku dan perhatiannya pada pasien setiap saat. Komunikasi yang efektif antara dokter dan pasien sangatlah diperlukan untuk memperoleh hasil yang optimal, berupa masalah kesehatan yang dapat diselesaikan dan kesembuhan pasien. (Rusmana, 2009; Hardjodisastro, 2010).

Hasil penelitian dan pengamatan menunjukkan bahwa komunikasi antara dokter dan pasien di Indonesia belum menjadi urusan utama. Selama ini kompetensi komunikasi cenderung terabaikan. Banyak tuduhan bahwa dokter melakukan malpraktek. Juga terdapat fenomena pasien berbondong-bondong berobat ke luar negeri (Rusmana, 2009; Hardjodisastro, 2010). Berdasarkan hasil konsil kedokteran Indonesia, diketahui bahwa sebagian dokter di Indonesia merasa tidak mempunyai waktu yang cukup untuk berbincang-bincang dengan pasiennya, sehingga hanya bertanya seperlunya. Akibatnya, dokter sangat mungkin tidak mendapatkan keterangan yang cukup untuk menegakkan diagnosis dan menentukan perencanaan dan tindakan 
lebih lanjut. selain itu, pada pasien umumnya merasa berada dalam posisi yang lebih rendah di hadapan dokter, sehingga takut bertanya dan hanya menjawab sesuai pertanyaan dokter. Tidak mudah bagi dokter untuk menggali keterangan dari pasien karena pemahaman menyeluruh memang tidak diperoleh dalam waktu yang singkat. (Konsil Kedokteran Indonesia, 2006).

Menurut Yusa (2006), komunikasi efektif mampu mempengaruhi emosi pasien dalam pengambilan keputusan tentang rencana tindakan selanjutnya, sedangkan komunikasi tidak efektif akan mengundang masalah. Perlu dibangun komunikasi efektif yang dilandasi keterbukaan, kejujuran dan pengertian akan kebutuhan, harapan, maupun kepentingan masingmasing. Dengan terbangunnya komunikasi yang efektif, pasien akan memberikan keterangan yang benar dan lengkap sehingga dapat membantu dokter dalam mendiagnosis penyakit pasien secarabaik dan memberi obat yang tepat bagi pasien. Komunikasi yang baik dan berlangsung dalam kedudukan setara sangat diperlukan agar pasien mau dan dapat menceritakan sakit serta keluhanyang dialaminya secara jujur dan jelas.

Menurut Rusmana (2009), empat keinginan pasien yang harus dipenuhi untuk membangun hubungan yang baik antara dokter dan pasien adalah:

1. Merasa ada jalinan dengan dokter dan mengetahui bahwa pasien memperoleh perhatian penuh dari dokter

2. Mengetahui bahwa dokter dapat fokus pada setiap tindakan pengobatan dan interaksinya

3. Merasa rileks dan bebas dari kekhawatiran pada suasana ruang praktek

4. Mengetahui bahwa dokternya dapat diandalkan.

Dari sudut pandang pasien, hubungan yang terjalin akan meningkatkan kepercayaan dan komunikasi yang efektif. Dokter akan tanggap pada respon pasien atas informasi yang disampaikannya. Pasien akan lebih terbuka dalam mendengar dan belajar. Pertukaran pandangan yang sama akan mudah dikembangkan dan pasien lebih bersedia untuk melakukan tindakan yang sesuai harapannya. Pasien menjadi lebih siap menerima tindakan pengobatan dan akan menyarankan orang lain ke dokter yang memiliki hubungan baik dengannya.

\section{PENGERTIAN KOMUNIKASI}

Secara umum, definisi komunikasi adalah sebuah proses penyampaian pikiran-pikiran atau informasi dari seseorang kepada orang lain melalui suatu cara tertentu sehingga orang lain tersebut mengerti apa yang dimaksud oleh penyampai pikiran-pikiran atau informasi. (Komaruddin, 1994; Schermerhorn, Hunt \& Osborn, 1994; Koontz \& Weihrich, 1988). Secara sederhana, kegiatan komunikasi dipahami sebagai kegiatan penyampaian dan penerimaan pesan atau ide dari satu pihak ke pihak lain, dengan tujuan untuk mencapai kesamaan pandangan atas ide yang dipertukarkan tersebut (Ruben dkk, 1998; Gorden, 1978).

Kegiatan komunikasi sudah menjadi sebagian besar kegiatan setiap orang sehari-hari, mulai antar teman, kelompok, organisasi atau massa. Kalau lebih teliti lagi banyak kegagalan dari komunikasi yang dilakukan. Penyebabnya dikarenakan banyak hal, antara lain tidak adanya saling kesepahaman, belum bertambahnya informasi, serta belum ada usaha perubahan tingkah laku pada orang yang dituju.

Komunikasi adalah keterampilan yang sangat penting dan merupakan hal yang paling dekat dalam kehidupan manusia, dapat diketahui bahwa komunikasi terjadi pada setiap gerak langkah manusia. Manusia adalah makhluk sosial yang tergantung satu sama lain, serta saling terkait dengan orang lain di lingkungannya. Satu-satunya alat untuk dapat berhubungan dengan 
orang lain di dalam lingkungan adalah melalui komunikasi, baik secara verbal maupun non verbal.

Terdapat berbagai definisi dari komunikasi. Definisi-Definisi yang timbul dilatarbelakangi oleh berbagai perspektif seperti mekanis, sosiologis, atau psikologis. Komunikasi sebagai aktivitas esensial manusia, memiliki makna yang benar-benar luas. Mulai dari penyampaian energi, gelombang suara, tanda di antara tempat, sistem atau organisme. Komunikasi secara terminologis adalah proses penyampaian suatu pernyataan oleh seseorang kepada orang lain. Berdasarkan pengertian tersebut dapat diketahui bahwa komunikasi melibatkan sejumlah orang, atau komunikasi yang dimaksudkan adalah komunikasi antar manusia. Kegiatan komunikasi pada prinsipnya adalah aktivitas pertukaran ide atau gagasan Komunikasi merupakan proses penyampaian informasi yang diterima oleh alat-alat indera, ke bagian otak. Informasi tersebut dapat berasal dari lingkungan, organisme lainnya, atau dari diri sendiri. Ditinjau dari sudut pandang ilmu Biologi, proses penyampaian informasi merupakan suatu proses yang teramat rumit dan kompleks. Hasil dari sinergi otak dengan berbagai alat indera dan organ-organ tubuh, serta melibatkan jutaan sel syaraf di otak dan seluruh bagian tubuh (Mulyana \& Deddy, 2001).

Aplikasi definisi komunikasi dalam interaksi antara dokter dan pasien diartikan sebagai tercapainya pengertian dan kesepakatan yang dibangun dokter bersama pasien pada setiap langkah penyelesaian masalah pasien. Untuk sampai pada tahap tersebut, diperlukan berbagai pemahaman seperti pemanfaatan jenis komunikasi (lisan, tulisan), menjadi pendengar yang baik, adanya penghambat proses komunikasi, pemilihan alat penyampai pikiran atau informasi yang tepat, dan mengekspresikan perasaan dan emosi. Selanjutnya definisi tersebut menjadi dasar model proses komunikasi yang berfokus pada pengirim pikiran-pikiran atau informasi, saluran yang dipakai untuk menyampaikan pikiran-pikiran atau informasi, dan penerima pikiran-pikiran atau informasi.

Model tersebut juga akan mengilustrasikan adanya penghambat pikiran-pikiran atau informasi sampai ke penerima, dan umpan balik yang memfasilitasi kelancaran komunikasi itu sendiri. Dalam hubungan dokter-pasien, baik dokter maupun pasien dapat berperan sebagai sumber atau pengirim pesan dan penerima pesan secara bergantian. Pasien sebagai pengirim pesan, menyampaikan apa yang dirasakan atau menjawab pertanyaan dokter sesuai pengetahuannya. Sementara dokter sebagai pengirim pesan, berperan pada saat menyampaikan penjelasan penyakit, rencana pengobatan dan terapi, efek samping obat yang mungkin terjadi, serta dampak dari dilakukan atau tidak dilakukannya terapi tertentu.

Dokter bertanggung jawab untuk memastikan pasien memahami apa yang disampaikan. Sebagai penerima pesan, dokter perlu berkonsentrasi dan memperhatikan setiap pernyataan pasien. Untuk memastikan apa yang dimaksud oleh pasien, dokter sesekali perlu membuat pertanyaan atau pernyataan klarifikasi. Mengingat kesenjangan informasi dan pengetahuan yang ada antara dokter dan pasien, dokter perlu mengambil peran aktif. Ketika pasien dalam posisi sebagai penerima pesan, dokter perlu secara proaktif memastikan apakah pasien benar benar memahami pesan yang telah disampaikannya.

Elemen-elemen yang terdapat dalam komunikasi menurut Gorden (1978) adalah:

1. Komunikator : orang yang menyampaikan pesan

2. Pesan : ide atau informasi yang disampaikan

3. Media : sarana komunikasi

4. Komunikan : pihak yang menerima pesan 
5. Umpan Balik : respon dari komunikan terhadap pesan yang diterimanya.

Lima sasaran pokok dalam proses komunikasi, yaitu:

1. Membuat komunikan mendengarkan atau melihat apa yang komunikator katakan

2. Membuat komunikan memahami apa yang mereka dengar atau lihat

3. Membuat komunikan menyetujui apa yang telah mereka dengar

4. Membuat komunikan mengambil tindakan yang sesuai dengan maksud komunikator, dan maksudnya dapat diterima oleh komunikan

5. Memperoleh umpan balik dari komunikan.

\section{KOMUNIKASI EFEKTIF}

Tujuan komunikasi adalah segala bentuk aktivitas yang dilakukan oleh individu dengan tujuan menyampaikan pesannya pada orang lain. Jika pesan yang dimaksudkan tersebut tidak sesuai dengan penangkapan lawan bicara, maka kemungkinan besar akan menyebabkan terjadinya miskomunikasi, sehingga berdasarkan hal tersebut dibutuhkan suatu bentuk komunikasi yang efektif.

Komunikasi dapat efektif apabila pesan diterima dan dimengerti sebagaimana dimaksud oleh pengirim pesan, pesan ditindaklanjuti dengan sebuah perbuatan oleh penerima pesan dan tidak ada hambatan untuk hal itu (Hardjana, 2003).

Hukum komunikasi efektif yang banyak dibahas diberbagai literatur disingkat dalam satu kata, yaitu REACH, yang dalam bahasa Indonesia berarti meraih ( Hanas, 2009; Prijosaksono, 2002; Rusoni, 2007; Toha, 2008).

\section{Respect}

Sikap menghargai mengacu pada proses menghargai setiap individu yang menjadi sasaran pesan yang disampaikan oleh komunikator. Jika individu membangun komunikasi dengan rasa dan sikap saling menghargai dan menghormati, maka kerjasama yang menghasilkan sinergi dapat dibangun, yang akan meningkatkan efektifitas kinerja, baik sebagai individu maupun secara keseluruhan.

\section{Humble}

Sikap rendah hati mengacu pada sikap yang penuh melayani, sikap menghargai, mau mendengar dan menerima kritik, tidak sombong dan memandang rendah orang lain, berani mengakui kesalahan, rela memaafkan, lemah lembut dan penuh pengendalian diri, serta mengutamakan kepentingan yang lebih besar.

\section{Empathy}

Empati adalah kemampuan individu untuk menempatkan diri pada situasi atau kondisi yang dihadapi oleh orang lain. Salah satu prasyarat utama dalam memiliki sikap empati adalah kemampuan untuk mendengarkan atau mengerti terlebih dulu sebelum didengarkan atau dimengerti oleh orang lain. Rasa empati membantu individu dalam menyampaikan pesan dengan cara dan sikap yang akan memudahkan penerima pesan menerimanya. Jadi sebelum membangun komunikasi atau mengirimkan pesan, individu perlu mengerti dan memahami dengan empati calon penerima pesan. Sehingga nantinya pesan dari komunikator akan dapat tersampaikan tanpa ada halangan psikologis atau penolakan dari penerima.

\section{Audible}

Makna dari audible adalah dapat didengarkan atau dimengerti dengan baik oleh penerima pesan.

5. Clarity 
Kejelasan, terkait dengan kejelasan dari pesan itu sendiri sehingga tidak menimbulkan multi interpretasi atau berbagai penafsiran yang berlainan. Kejelasan juga berarti keterbukaan dan transparansi. Dalam berkomunikasi, individu perlu mengembangkan sikap terbuka, sehingga dapat menimbulkan rasa percaya dari penerima pesan.

\section{KOMUNIKASI EFEKTIF DOKTER-PASIEN}

Komunikasi dokter-pasien merupakan salah satu kompetensi yang harus dikuasai dokter. Kompetensi komunikasi menentukan keberhasilan dalam membantu penyelesaian masalah kesehatan pasien. Komunikasi yang efektif diharapkan dapat mengatasi kendala yang dialami oleh kedua belah pihak. Kurtz (1998) menyatakan bahwa komunikasi efektif justru tidak memerlukan waktu lama. Komunikasi efektif terbukti memerlukan lebih sedikit waktu karena dokter terampil mengenali kebutuhan pasien. Dalam pemberian pelayanan medis, adanya komunikasi yang efektif antara dokter dan pasien merupakan kondisi yang diharapkan sehingga dokter dapat melakukan manajemen pengelolaan masalah kesehatan bersama pasien, berdasarkan kebutuhan pasien.

Menurut Kurzt (1998), dalam dunia kedokteran ada dua pendekatan komunikasi yang digunakan:

1. Disease centered communication style atau doctor centered communication style. Komunikasi berdasarkan kepentingan dokter dalam usaha menegakkan diagnosis, termasuk penyelidikan dan penalaran klinik mengenai tanda dan gejala-gejala.

2. Illness centered communication style atau patient centered communication style. Komunikasi berdasarkan apa yang dirasakan pasien tentang penyakitnya yang secara individu merupakan pengalaman unik. Keberhasilan komunikasi antara dokter dan pasien pada umumnya akan melahirkan kenyamanan dan kepuasan bagi kedua belah pihak.

Tujuan komunikasi yang relevan dengan profesi dokter menurut Yusa, 2006 adalah:

1. Memfasilitasi terciptanya pencapaian tujuan kedua pihak (dokter dan pasien).

2. Membantu pengembangan rencana perawatan pasien bersama pasien, untuk kepentingan pasien dan atas dasar kemampuan pasien, termasuk kemampuan finansial.

3. Membantu memberikan pilihan dalam upaya penyelesaian masalah kesehatan pasien.

4. Membimbing pasien sampai pada pengertian yang sebenarnya tentang penyakit atau masalah yang dihadapinya.

5. Membantu mengendalikan kinerja dokter dengan acuan langkah-langkah atau hal-hal yang telah disetujui pasien.

Tujuan dari komunikasi efektif antara dokter dan pasiennya adalah untuk mengarahkan proses penggalian riwayat penyakit lebih akurat untuk dokter, lebih memberikan dukungan pada pasien, dengan demikian lebih efektif dan efisien bagi keduanya (Kurtz, 1998).

Menurut Konsil Kedokteran Indonesia (2006), berdasarkan hari penelitian, manfaat komunikasi efektif dokter-pasien adalah:

1. Meningkatkan kepuasan pasien dalam menerima pelayanan medis dari dokter atau institusi pelayanan medis.

2. Meningkatkan kepercayaan pasien kepada dokter yang merupakan dasar hubungan dokterpasien yang baik.

3. Meningkatkan keberhasilan diagnosis terapi dan tindakan medis. 
4. Meningkatkan kepercayaan diri dan ketegaran pada pasien fase terminal dalam menghadapi penyakitnya.

\section{LANGKAH-LANGKAH DALAM MEWUJUDKAN KOMUNIKASI EFEKTIF DOKTER-PASIEN}

Berdasarkan hasil Konsil Kedoteran Indonesia (2006), yang perlu diperhatikan dalam meningkatkan komunikasi efektif antara dokter dan pasien adalah :

1. Sikap profesional dokter, sikap yang menunjukkan kemampuan dokter dalam menyelesaikan tugas-tugas sesuai peran dan fungsinya, mampu mengatur diri sendiri seperti ketepatan waktu, dan mampu menghadapi berbagai tipe pasien, serta mampu bekerja sama dengan profesi kesehatan yang lain. Di dalam proses komunikasi dokter-pasien, sikap profesional penting untuk membangun rasa nyaman, aman, dan percaya pada dokter, yang merupakan landasan bagi berlangsungnya komunikasi secara efektif (Silverman, 1998).

2. Pengumpulan informasi, yang di dalamnya terdapat proses anamnesis yang akurat, dan sesi penyampaian informasi.

3. Penyampaian informasi yang akurat.

4. Proses langkah-langkah komunikasi, yang terdiri dari salam, ajak bicara, menjelaskan, dan mengingatkan pasien.

Dengan mengembangkan komunikasi efektif tersebut, dokter dapat mengetahui sepenuhnya kondisi pasien dan keluarga pasien juga menaruh kepercayaan sepenuhnya kepada dokter. Kondisi tersebut dapat berpengaruh pada proses penyembuhan pasien selanjutnya. Pasien merasa aman dan tenang mendapatkan penanganan yang intensif oleh dokter, sehingga pasien akan patuh menjalankan petunjuk dan nasehat dokter karena yakin bahwa semua yang dilakukan untuk kebaikan pasien.

\section{SIMPULAN}

Pasien adalah setiap orang yang menjalani konsultasi masalah kesehatannya untuk memperoleh pelayanan kesehatan yang diperlukan baik secara langsung maupun tidak langsung kepada dokter. Kunjungan ke dokter dilakukan sebagai upaya memperoleh jawaban atas kondisi kesehatannya dan harapan untuk dapat sembuh. Aspek yang cukup dominan mempengaruhi keputusan pasien dalam berobat ke dokter adalah komunikasi. Sikap dokter dalam berkomunikasi dengan pasien dapat menimbulkan kesimpulan yang akan mempengaruhi keputusan pasien.

Dokter perlu relevan dan efektif memahami bahwa yang dimaksud dengan komunikasi tidaklah hanya sekadar komunikasi verbal, melalui percakapan, namun juga mencakup pengertian komunikasi secara menyeluruh. Dokter perlu memiliki kemampuan untuk menggali dan bertukar informasi secara verbal dan nonverbal dengan pasien pada semua usia, anggota keluarga, masyarakat, kolega dan profesi lain. Dalam paradigma baru yang senapas dengan ketentuan undang-undang, hubungan dokter-pasien adalah kemitraan. Pasien harus dihargai sebagai pribadi yang berhak atas tubuhnya. Menghormati dan menghargai pasien adalah sikap yang diharapkan dari dokter dalam berkomunikasi dengan pasien, tanpa mempedulikan berapa pun umurnya, tanpa memperhatikan status sosial-ekonominya. Bersikap adil dalam memberikan pelayanan medis adalah dasar pengembangan komunikasi efektif dan menghindarkan diri dari perlakuan diskriminatif terhadap pasien. 
Efektif atau tidaknya komunikasi yang berlangsung akan menentukan sikap pasien dalam menerima diagnosis yang ditetapkan dokter, menjalani pengobatan, melakukan perawatan diri dan memerhatikan atau mematuhi anjuran dan nasihat dokter. Komunikasi tersebut juga mempengaruhi kelangsungan terapi, apakah akan berlanjut atau terjadi pemutusan hubungan secara sepihak. Reaksi pasien ketika masih berada dalam ruang praktek, sikap pasien pada kunjungan ulang, cara pasien melaksanakan pengobatan adalah umpan balik bagi dokter, untuk mengetahui hasil komunikasinya.

\section{DAFTAR PUSTAKA}

Gorden, W I. (1978). Communication: Personal and Public. diunduh tanggal 18 Desember 2009 Konsil Kedokteran Indonesia. (2006). Komunikasi Efektif Dokter-Pasien. Jakarta: KKI.

Koontz., Weihrich (1988), Management, 9th ed, Mc Graw Hill Inc, Singapore, pp.461 -465

Kurtz, S., Silverman, J. \& Drapper, J. (1998). Teaching and Learning Communication Skills in Medicine. Oxon: Radcliffe Medical Press.

Mulyana., Deddy. (2001). Ilmu Komunikasi: Suatu Pengantar. Bandung: Rosda

Ruben., Brent D., Stewart., Lea P. (2005). Communication and Human Behaviour,USA:Alyn and Bacon

Rusmana, A. (2009). Komunikasi Efektif Dokter Gigi vs Pasien. diunduh tanggal 18 Januari 2010

Silverman, J., Kurtz, S. \& Drapper, J. (1998). Skills for Communicating with Patients. Oxon: Radcliffe Medical Press.

Waitzkin dan Waterman. (1993). Sosiologi Kesehatan. Jakarta: Prima Aksara

Whitcomb, M.E. (2000). Communication and Professionalism, Patient Education and Counseling, 41: 134-144 